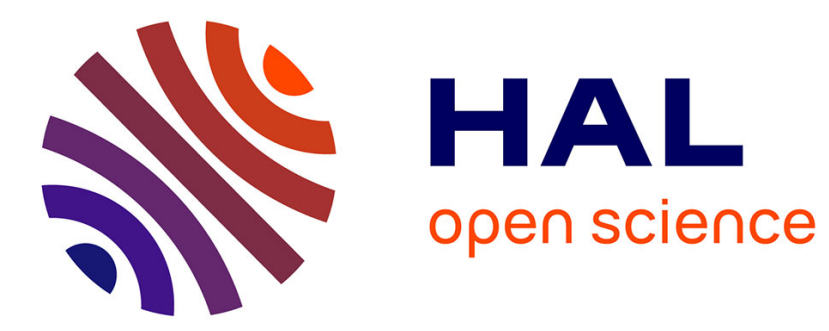

\title{
NON DESTRUCTIVE EVALUATION OF COMPOSITE MATERIALS USING ULTRASONIC SPECTROSCOPY
}

\author{
Mohamed Ourak, Bertrand Nongaillard, Jean-Michel Rouvaen, N. \\ Imouloudene
}

\section{To cite this version:}

Mohamed Ourak, Bertrand Nongaillard, Jean-Michel Rouvaen, N. Imouloudene. NON DESTRUCTIVE EVALUATION OF COMPOSITE MATERIALS USING ULTRASONIC SPECTROSCOPY. Journal de Physique Colloques, 1990, 51 (C2), pp.C2-1261-C2-1264. 10.1051/jphyscol:19902296 . jpa-00230630

\section{HAL Id: jpa-00230630 https://hal.science/jpa-00230630}

Submitted on 1 Jan 1990

HAL is a multi-disciplinary open access archive for the deposit and dissemination of scientific research documents, whether they are published or not. The documents may come from teaching and research institutions in France or abroad, or from public or private research centers.
L'archive ouverte pluridisciplinaire HAL, est destinée au dépôt et à la diffusion de documents scientifiques de niveau recherche, publiés ou non, émanant des établissements d'enseignement et de recherche français ou étrangers, des laboratoires publics ou privés. 
COLLOQUE DE PHYSIQUE

Colloque C2, supplément au $n^{\circ} 2$, Tome 51, Février 1990

ler Congrès Français d'Acoustique 1990

\title{
NON DESTRUCTIVE EVALUATION OF COMPOSITE MATERIALS USING ULTRASONIC SPECTROSCOPY (1)
}

\author{
M. OURAK, B. NONGAILLARD, J.M. ROUVAEN and N. IMOULOUDENE \\ Laboratoire d'opto-Acousto-Electronique, CNRS URA 832, ENSIMEV, \\ Universite de Valenciennes, F-59326 Valenciennes Cedex, France
}

\begin{abstract}
Résumé - Les matériaux composìtes carbone-époxy, très utilisês dans 1 'industrie aéronautique, sont très dẻlicats à contrôler. Les méthodes classiques de contrôle sont en particulier insuffisantes pour la détection des défauts répartis (porosités, délaminations) qui altèrent gravement les propriétés mécaniques des structures. Les ultrasons permettent de détecter certaines délaminations (échographie mode A), mais I'interprétation du signal temporel reste assez ardue dans le cas des porosités et compte-tenu de 1 'hêtérogénéité des matériaux composites. L'intẻrêt de 1 'analyse spectrale est démontré dans la présente communication : elle met en évidence en onde longitudinale des fréquences privilégiées d'absorption, étroitement liées à la structure interne du matériau composité étudié. Plusieurs exemples d'utilisation du spectre ultrasonore réfléchi ou transmis sont présentés pour différents échantillons sains ou poreux.
\end{abstract}

\begin{abstract}
The non destructive evaluation of the carbon epoxy composite materials (often used in aeronautics) is a difficult matter. The classical control methods prove unsatisfactory for the detection of distributed defects (like delaminations and porosities), which affect severely the mechanical properties of composite parts. Ultrasonic echography (A scan mode) allows for the detection of some kinds of delaminations, but the interpretation of the echographic signal remains difficult in the case of porosities and owing to the heterogeneous nature of composites. In the present comnunication, the usefulness of a spectral analysis (ultrasonic spectroscopy) is demonstrated : the occurence of selective absorption frequencies, closely bound to the material internal structure, is evidenced. Several examples of spectral analysis of the transmitted or reflected ultrasound are presented for reasonably defect-free and porous materials.
\end{abstract}

\section{1 - INTRODUCTION}

Composite materials allow for the realization of light parts, with a very high mechanical tenacity and a good resistance to corrosive agents, owing to their basic design and their physical properties. Their application domain is then growing very rapidly : transportation (by road, railway or air), aeronautics and space, and, even, sport /1/.

Among composite materials, we may give the examples of glass epoxy materials, often used in the automotive and maritime industries, or of carbon epoxy ones, more costly but also more efficient for applications in the aeronautic industry.

Some potential defects are introduced during the fabrication process of composite materials, among which :

- the delaminations bound to their multilayer nature,

- the porosities induced by their heterogeneous character (mainly due to air bubbles which can't freely migrate during the fabrication).

The development of composite materials is actually somewhat slowed down by the lack of convenient non destructive evaluation (N.D.E.) methods, these materials being heterogeneous and anisotropic and, so, difficult to analyze. A number of classical methods are tried ( $X$ rays, thermography, eddy currents, acoustic emission ...)/2/3.

The work reported here is aimed to the N.D.E. of composite materials using ultrasound, another often used technics in the industry at the production stage or in the laboratory. The ultrasonic N.D.E. is generally based on the interpretation of an echographic time diagram. However, in our particular case, the heterogeneities induce extraneous acoustic noise which may mask the reflections from the defects.

(1) This work was supported by the "Direction des Recherches et Etudes Techniques" Paris FRANCE 
The time signal may then be difficult to interpret in most cases, so we resort here to the use of ultrasonic spectroscopy.

\section{2 - THE TIME DIAGRAM AND ITS LIMITATION IN THE N.D.E. OF COMPOSITE MATERIALS.}

A classical electronic set up is used in our echographic experiments. The longitudinal mode ultrasonic transducer is driven by a pulse modulated continuous wave signal after electronic amplification, and the echographic signal is viewed on a scope monitor.

The echographic signal obtained from a reasonably defect-free carbon epoxy composite sample, with crossed fibers between successive plies (multidirectionnal, 32 plies) and a 3.3 mn thickness, is shown in Fig. 1. One may clearly distinguish the echo on the front (entrance) face of the sample, small intermediary echoes due to internal reflections (heterogeneities inside the sample) and the echo on its back face.

Hor : $500 \mathrm{~ns} /$ div. Vert : $100 \mathrm{mV} /$ div.

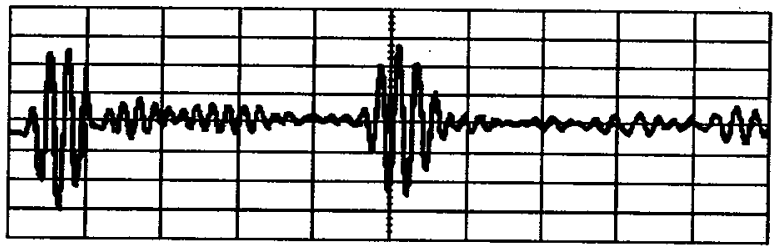

carrier freq. $10 \mathrm{MHz}$

Fig. 1 - Time diagran of the reflected ultrasonic signal for a defect-free carbon-epoxy composite.

For a sample identical in nature, but presenting a delamination between plies in a definite zone, the echo on the back face becomes hardly distinguishable. On another hand, using longitudinal waves under normal incidence, an absorption of the electronic carrier is observed in the back face echo, when it comes near a frequency of $10.8 \mathrm{MHz}$, as shown in Fig. 2 .

Hor : $500 \mathrm{~ns} /$ div. $\quad$ Vert : $40 \mathrm{mV} /$ div.

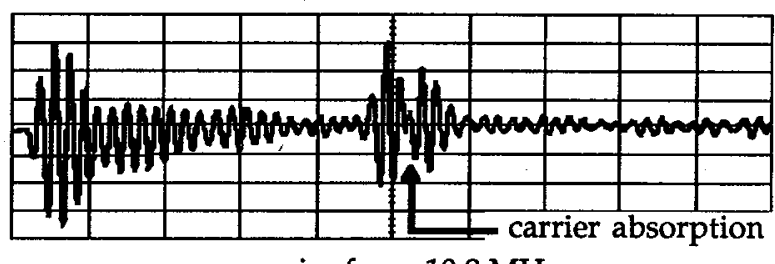

carrier freq. $10,8 \mathrm{MHz}$

Fig. 2 - Absorption of the electronic carrier in the back face echo.

This phenomenon is also observed for samples containing reasonable porosities, the excessive attenuation preventing the detection of the back face echo when the porosity becomes severe. The only way to get a more detailed information about this absorption phenomenon is to determine the frequency response of the sample and, then, to use ultrasonic spectroscopy.

\section{3 - ULTRASONIC SPECTROSCOPY.}

The enveloppe of the reflected (or transmitted) echo inside the material depends on the nature and the internal structure of the sample, together with the incidence angle of the ultrasonic bean on its front face.

The results obtained using longitudinal ultrasonic waves are given in the following. It may first be stated that analogous experience have been performed using shear ultrasonic waves in another laboratory $/ 4 /$, which evidence also a similar phenomenon at frequencies clearly related to the periodicity of the fiber orientation in the successive plies. This is somewhat confirmed by our experiments (for samples with the same nature and number of plies, but with a differing periodic arrangement of plies, the absorption is observed at different frequencies). However, the relationship between the previous periodicity and the value of the absorption 
frequency doesn't appear straightforward in our case.

The spectrum of the signal reflected on the back face of the sample around the $10 \mathrm{MHz} c a r r i e r$ frequency has been first studied. It has been verified that an isotropic plexiglass sample doesn't exhibit any absorption frequency. For a composite carbon epoxy sample (3.3 mm thick) an absorption dip is however observed at $10.8 \mathrm{MHz}$ as shown in Fig. 3.

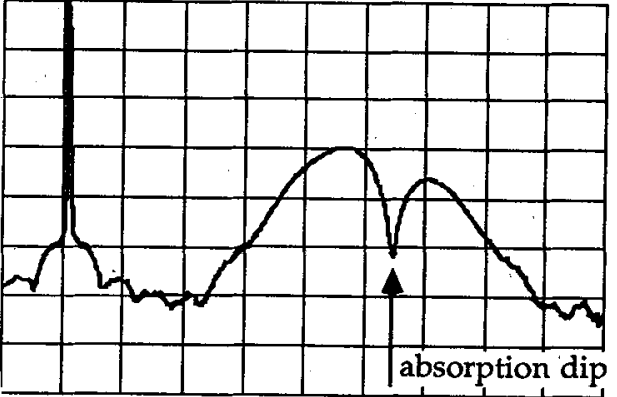

Horiz. $2 \mathrm{MHz} /$ div

Fig. 3. Spectrum of the echo reflected on the back face

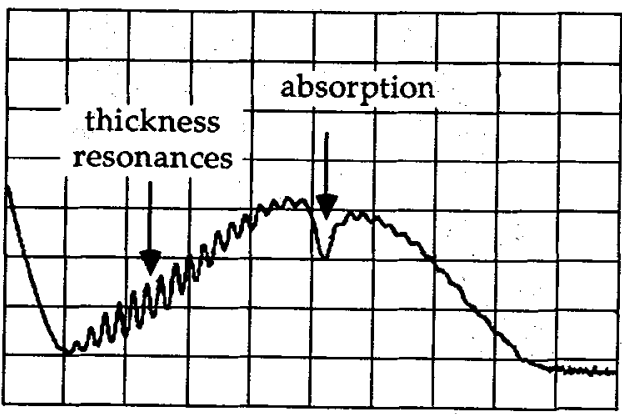

Horiz. $2 \mathrm{MHz} / \mathrm{div}$

Fig. 4. Spectrum of the transmitted signal

The Fig. 4 shows the spectrum of the signal transmitted through the same sample. A supplementary modulation of the response envelope (also encountered for isotropic samples) arises from the thickness resonances of the material (standing waves), the frequency gap between two successive maxima (or minima) being given by $f=v / 2 e$ (where $v$ stands for the ultrasonic wave velocity and $e$ for the sample thickness).

By using another ultrasonic probe driven at a higher frequency ( $30 \mathrm{MHz}$ ) absorption dips may also be evidenced near the harmonics of the previous fundamental absorption frequency.

Some other experiments have been conducted for a varying incidence angle of the longitudinal ultrasonic beam. It was found that the absorption frequencies depend on the value of the incidence angle. Moreover, some other phenomena may arise, like the mode conversion to shear ultrasonic waves during the reflection under oblique incidence on the sample faces or the generation of several guided modes with different velocities, leading to several more or less marked absorption dips in the spectrum.

\section{4 - INTERPRETATION OF THE ABSORPTION PHENOMENON.}

As the absorption shows up in both the reflection and transmission modes of operation, one may at first sight think that the source of this phenomenon lies in the generation of guided ultrasonic waves by mode conversion on the carbon fibers. At the absorption frequency, this generation occurs synchronously in each ply, and a significative fraction of the incident wave energy may then be extrated, which leads to the absorption dips in the reflected and transmitted spectra.

Under normal incidence, if $p$ stands for the spatial period, $T$ for the time period at the absorption frequency and $v_{g}$ for the guided wave phase velocity, the relationship $v_{p}=p / T$ must hold/5/. This leads to a velocity around $160 \mathrm{~m} / \mathrm{s}$ for an absorption frequency of $10.8 \mathrm{MHz}$ and a spatial period of $15 \mathrm{~m}$. The behavior of this guided wave is much like that of fundamental antisymmetric Lamb waves (mode $a_{0}$ )/6/. Such a kind of slow wave seems to be hardly observable, since it suffer from a prohibitive ultrasonic attenuation.

A visualization experiment (Schlieren method ) has been performed in order to bring another proof of the absorption phenomenon for the reflected and transmitted energies (see photos 1 and 2 of Fig. 5).

\section{5 - VALUE DF THE ULTRASONIC SPECTROSCOPY METHOD FOR THE N.D.E. OF COMPOSITES.}

The appearance of the transmitted or reflected spectrum may give informations about the defects distributed in the bulk of the samples. The transmitted spectrum of a porous composite sample is given in Fig. 6.

It may prove interesting to study the evolution of the spectrum around the absorption frequency with the presence and nature of detects. 


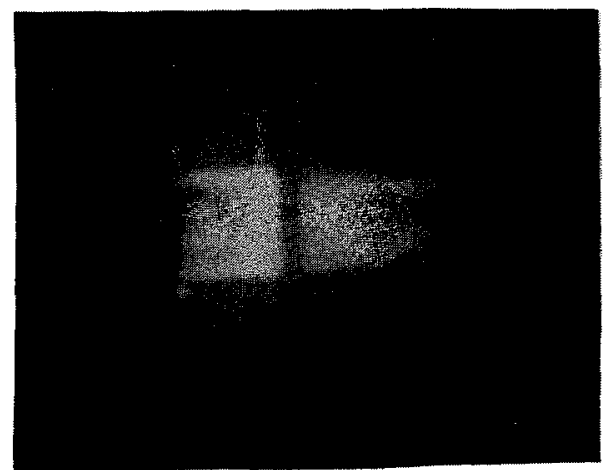

$-1$

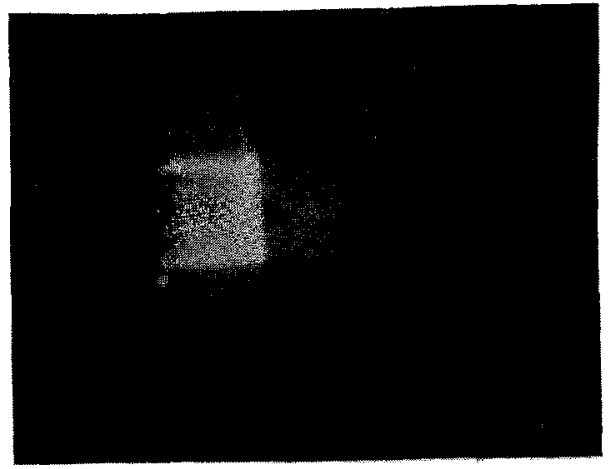

$-2$

Fig. 5 - Visualization of the transmitted ultrasonic signal : photo 1 driving frequency $10 \mathrm{MHz}$ good transmission - photo 2 driving frequency $10.8 \mathrm{MHz}$ absorption (no transmitted energy).

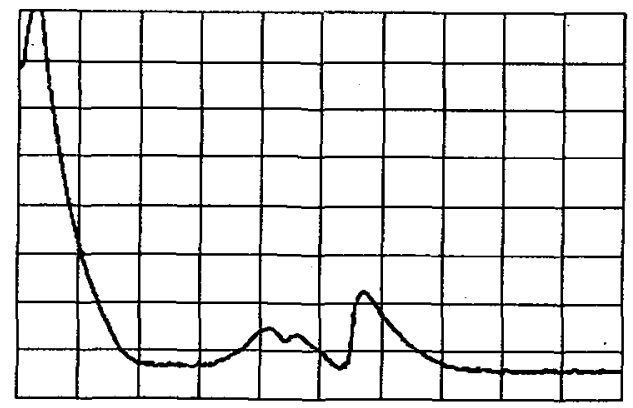

Horiz. $2 \mathrm{MHz} /$ div

Fig. 6 - Ultrasonic energy spectrum of the signal transmitted through a porous sample.

6 - CONCLUSION.

The presence of absorption frequencies in the spectrum of the longitudinal wave energy transmitted through or reflected from carbon-epoxy composite samples has been evidenced using u1trasonic spectroscopy. The N.D.E. of these materials at frequencies near these absorption ones may bring informations about the presence of distributed defects (porosities) or stacking defects (periodicity of the ply orientation).

\section{REFERENCES}

/1/ Matériaux composites, D. Gay, ed. Hermes (Paris), 1987.

/2/ Les matériaux composites, tome 2, J. Weiss and C. Bord, Edition de 1'Usine Nouvelle (Paris), 1983.

/3/ Contrôle non destructif des matériaux composites - Etat actuel et perspective. CETIM informations $\mathrm{n}^{\circ} 84$, Février 1984 .

/4/ M. Fink, private communication (to be published).

/5/ Acoustic bulk surface wave transducer, R.F. Humphryes and E.A. Ash, Electron. Lett. Vol.5, $\mathrm{n}^{\circ} 9$, p. 175, 1969.

/6/ Rayleigh and Lamb waves, I.A. Viktorov, Plenum Press (New-York), 1967.

ACKNOWLEDGEMENTS

We gratefully acknowledge the "Laboratoire Central de Recherche de l'Aérospatiale" in Suresnes (France) and the Society M.D.B.A. in Saint-Cloud (France) for their collaboration and the furniture of the carbon-epoxy composite samples. 